\title{
Dutch role in hostage crisis
}

PAUL BROUWER, then Ambassador for the Netherlands in Indonesia, tells in the Dutch radio programme Argos (5 November 1999) about the good cooperation between the Indonesians, British and Dutch.

\section{A translation:}

Brouwer: I had two people detached there who took turns. The experience is that in such a place you are so much under pressure that you have to get out from time to time. Therefore, I had there alternately the military attaché, Colonel De Mars, and the head of the consular department, for those contacts and to be present constantly with the consultations, to take part in the briefings, the preparations, and to partake in all the dealings. Of course, those two were in continuous contact with the Embassy through direct lines. And also very close with the British who did it in exactly the same way. Also, because on the spot things were very informal: afeeling of solidarity developed there rather quickly - that they were together settling a case.

ARGOS: This means that the different steps that were taken were thoroughly considered/shared?

Brouwer: There was good consultation.

ARGOS: It was not so that Indonesia was the boss?

Brouwer: No, no, no, certainly not. There was good consultation, both with the Red Cross and with the military. And certainly too with the British. Regarding the British and the Netherlands: for five months we dealt with that case in complete solidarity.

ARGOS: Was that also true for the last steps?

Brouwer: That was especially true for Jakarta where the British Ambassador and I had daily, sometimes several times a day, contact. It was clear that this was a case that concerned both of us together, also at the highest level of the Ambassador. We needed it because of the political attention on the case, but also to be able to have contact with the military about this. Especially in Indonesia, this was of course very important.

ARGOS: Does this also mean that there has been extensive consultation concerning the final solution that was chosen, the military intervention? $\leftrightarrow$ Continued overleaf 


\section{DUTCH ROLE IN HOSTAGE CRISIS}

$\circlearrowleft$ From previous page

Brouwer: When the Red Cross, during the so-called pig feast in Geselema, was confronted with the ultimate, blunt refusal of that one hostage-taker, the leader, to cooperate...

ARGOS: ....Kelly Kwalik...

Brouwer:...Yes... then it was clear to everybody on the ground, based on a communal evaluation: we could never get further than this. And if it breaks here, then we couldn't see how to solve this in a negotiated peaceful manner. And then this Indonesian military operation took off.

ARGOS: So, in that morning of 9 May 1996, it became clear: there would be a military intervention?

Brouwer: Yes.

ARGOS: And you were part of that decision-making?

Brouwer: Of course, things happened very quickly that day. Communication was always a problem. But that had been clear before. Because we all had, of course, several scenarios about what to do if it all broke down? Therefore, the Indonesian army had been preparing itselffor the possibility that an action might be necessary. But there was a very clear mutual understanding that the Indonesian army would not start an action on its own initiative.

ARGOS: Was the Netherlands involved in the nature of the military intervention? At some stage it must be clear that it was going to happen. But what exactly was going to happen and the way in which it would happen, was the Netherlands involved in this?

Brouwer: No. Except that De Mars being on the spot, of course, had good contact with the Indonesian operational troops and had informal talks with them, we have not been involved officially in the way it was going to happen that day. At least, in the first instance it was their action. But that doesn't mean to say that we didn't want to be there and didn't want to know what happened.

Translation provided by by Ottis Simopiaref, of the Papuan People's Foundation Study and Information Centre. ottismanswam@netscape.net 